\title{
Nd:YAG LASER FABRICATION OF SILICON ELECTRODE PLATES FOR A COMBINED-MODE MICRO DIRECT METHANOL FUEL CELL
}

\section{(Fabrikasi Plat Elektrod Silikon dengan Laser Nd:YAG untuk Sel Bahan Api Metanol Langsung Mikro Bermod Gabungan)}

\author{
Umi Azmah Hasran ${ }^{1 *}$, Siti Kartom Kamarudin ${ }^{1,3}$, Burhanuddin Yeop Majlis ${ }^{2}$, Wan Ramli Wan Daud ${ }^{3}$, \\ Abdul Amir Hassan Kadhum ${ }^{3}$, Gandi Sugandi ${ }^{4}$ \\ ${ }^{1}$ Fuel Cell Institute \\ ${ }^{2}$ Institute of Microengineering and Nanoelectronics \\ ${ }^{3}$ Department of Chemical and Process Engineering \\ Universiti Kebangsaan Malaysia, 43600 UKM Bangi, Selangor, Malaysia \\ ${ }^{4}$ Research Center for Electronics and Telecommunication \\ Lembaga Ilmu Pengetahuan Indonesia, Bandung, Indonesia \\ *Corresponding author: umi.h@ukm.edu.my
}

Received: 13 April 2017; Accepted: 17 April 2018

\begin{abstract}
A silicon wafer was microfabricated to produce a new combined-mode flow field for the purpose of distributing methanol fuel throughout the anode side of a micro direct methanol fuel cell (DMFC). Active mode of operation, which generally produces more power, is more suited to higher power requirements compared with the passive mode. Different power outputs using different modes may be required during cell operation by devices that can potentially use the micro DMFC. The new flow field design in the electrode structure of the micro DMFC must manage the methanol fuel transport in either active or passive mode. The flow field area was designed to obtain $50 \%$ of the $1 \mathrm{~cm}^{2}$ active reaction area of the membrane electrode assembly. The proposed design was simulated using COMSOL multi-physics software and microfabricated by incorporating two flow field designs on the anode plate, namely, the grid flow field for the active mode and the porous flow field for the passive mode. The silicon wafer used to produce the electrode plate was a $\langle 100\rangle$ p-type single-sided polished substrate and the MEMS-based microfabrication process to form the required electrode structures was dry etching with laser ablation. The current collector layers used were titanium/copper with a thickness of $1.1 \mu \mathrm{m}$ and gold with a thickness of $0.18 \mu \mathrm{m}$. The completed single-cell micro DMFC obtained a maximum performance of $1.86 \mathrm{~mW} / \mathrm{cm}^{2}$ at a voltage of $138.7 \mathrm{mV}$.
\end{abstract}

Keywords: anode flow field, MEMS technology, active mode, passive mode, dry etching technique

\begin{abstract}
Abstrak
Wafer silikon telah dimikrofabrikasi untuk menghasilkan medan aliran baru berbentuk mod gabungan bagi pengedaran bahan api metanol ke seluruh bahagian anod di dalam DMFC mikro. Mod operasi aktif, yang umumnya menghasilkan lebih banyak kuasa, adalah lebih sesuai dengan keperluan kuasa yang lebih tinggi berbanding mod operasi pasif. Output kuasa yang berbeza menggunakan mod yang berbeza dijangka diperlukan semasa operasi sel oleh peranti yang berpotensi menggunakan DMFC mikro. Reka bentuk medan aliran baru dalam struktur elektro DMFC mikro ini mesti menguruskan pengangkutan bahan api metanol sama ada dalam mod aktif atau pasif semasa operasi. Kawasan medan aliran direka untuk mendapatkan $\sim 50 \%$ daripada kawasan reaksi aktif $1 \mathrm{~cm}^{2}$ himpunan elektrod membran. Reka bentuk baru ini disimulasikan menggunakan perisian multifizik COMSOL dan dimikrofabrikasi dengan menggabungkan dua reka bentuk medan aliran pada sekeping plat anod, iaitu medan aliran grid untuk mod aktif dan medan aliran poros untuk mod pasif. Wafer silikon yang digunakan untuk menghasilkan plat elektrod adalah substrat <100> tergilap sebelah jenis-p dan proses mikrofabrikasi yang berasaskan MEMS untuk membentuk
\end{abstract}


struktur elektrod yang diperlukan adalah punaran kering dengan ablasi laser. Lapisan pengumpul arus adalah titanium/tembaga dengan ketebalan $1.1 \mu \mathrm{m}$ dan emas dengan ketebalan $0.18 \mu \mathrm{m}$. Sel tunggal DMFC mikro yang telah disiapkan dapat memberikan prestasi maksimum $1.86 \mathrm{~mW} / \mathrm{cm}^{2}$ pada voltan $138.7 \mathrm{mV}$.

Kata kunci: medan aliran anod, teknologi MEMS, mod aktif, mod pasif, proses punaran kering

\section{Introduction}

In this work, a silicon wafer was oxidized and micromachined with the required design to produce a flow channel for the purpose of distributing fuel and oxidant throughout anode and cathode areas, respectively. The reactants and by-products in a micro direct methanol fuel cell (DMFC) are typically moved throughout the active reaction site by using one of these transfer methods or operating modes at a time, that is, either active or passive modes. The flow channel is known as a flow field, and the flow plate is generally known as electrode plate or plate separator. The uniform distribution of reactants (i.e. diluted methanol as fuel and oxygen from the surrounding air as oxidant) and the effective removal of by-products (i.e., carbon dioxide and water) from the fuel cell is an important function of the flow field to reduce the polarization of methanol concentration and obtain an efficient fuel cell operation [1]. The functional components of a micro fuel cell are mainly the flow field (or electrode) plate, membrane electrode assembly (MEA), proton exchange membrane, catalytic layer, gas diffusion layer, and current collector [2].

In general, a fuel cell that operates in active mode generates more power than the ones operating in passive mode. The electrode plate design is typically developed by considering only one operating mode, which results in the usage of that mode during the entire operation. However, the power supply requirement may vary for the same application based on the operation of a device, e.g., electronic devices require more power during "talk mode" and can utilize the active design, whereas the "standby mode" is less power consuming and can utilize the passive design. The objective of this work was to create a new structure that manages the transport of fuel inside the cell by microfabricating a flow field design that incorporates active and passive mode features at the unit cell level on the anode plate. Therefore, the electrode plate design concept to be studied can give the resulting micro DMFC the ability to operate in both modes during operation. Focus was given on the anode flow field design because methanol fuel transportation has a major effect on the micro DMFC performance. Meanwhile, the cathode plate flow field design was micromachined with passive-mode features. Table 1 shows the types and characteristics of common electrode plate designs for an anode used in micro DMFC to select the most suitable combination of active and passive channels for the anode plate based on the advantages and disadvantages demonstrated by each design.

Table 1. Types and characteristics of common anode plate designs in micro DMFC

\begin{tabular}{|c|c|c|c|c|c|}
\hline & Type & Schematic & Advantages & Disadvantages & References \\
\hline (a) & Parallel & & $\begin{array}{l}\text { - A uniform distribution is } \\
\text { made but only in ideal } \\
\text { conditions. }\end{array}$ & $\begin{array}{l}\text { - Water droplets formed } \\
\text { during the reactions may } \\
\text { block the channels, and } \\
\text { fuel velocity from the } \\
\text { active mode operation may } \\
\text { not be enough to remove } \\
\text { them. } \\
\text { - A low and unstable cell } \\
\text { voltage is produced. }\end{array}$ & {$[3]$} \\
\hline (b) & $\begin{array}{l}\text { Single } \\
\text { Serpentine }\end{array}$ & & $\begin{array}{l}\text { - For a small-sized flow field, } \\
\text { this channel design typically } \\
\text { covers its entire active area. } \\
\text { - Water droplets formed in the } \\
\text { channel are pushed out of } \\
\text { the cell by high-speed } \\
\text { carbon dioxide gas bubble. }\end{array}$ & $\begin{array}{l}\text { - Fluid friction at the wall } \\
\text { and channel corner } \\
\text { increases the pressure drop } \\
\text { and reduces fuel } \\
\text { concentration. }\end{array}$ & [4] \\
\hline
\end{tabular}




\section{(e) Column, spot, grid, pin, or dot

HIII

(f) Porous
- This allows fluid to flow across the channel network to avoid problematic areas in the flow field.

- This is similar to a mesh design, except for the size of the pores and fabrication method, and it allows capillary action for fuel transport into the active area for reaction.
- Fluid may bypass parts of the channel due to pressure difference between the neighboring channels.

- This has low flow velocity and uneven flow distribution due to the inlet and exit positions.

- This is suitable only for small-sized micro fuel cells due to high pressure drop.
[4]

\section{Electrode plate design}

\section{Materials and Methods}

The new electrode structure highlights the concept of a combined-mode micro DMFC by incorporating two flow field designs on the anode plate, namely, the grid flow field (active mode) and the porous flow field (passive mode). The design of the electrode plate was determined based on the micro-electromechanical systems (MEMS) technology used to microfabricate the silicon substrate with the Miller index as a reference. During the planning stage, the limitations in the microfabrication process and the operation requirements of the micro DMFC were taken into account to ensure good distribution of reactants and removal of by-products in the anode and cathode channels. Table 2 summarizes the new design features that were selected for the anode and cathode plates.

Table 2. Design features of the new electrode plate

\begin{tabular}{llll}
\hline Plate & Mode & Flow Field Design & \\
\hline Cathode & Passive & Square through-hole & \\
Anode & Combined & Design 1: Active & Grid \\
& & Design 2: Passive & Porous
\end{tabular}

The process flow using laser ablation for flow field etching of the new anode plate design is shown in Figure 1, and it can be used for a combined active-passive micro DMFC mode. The grid flow field was a series of square-shaped platforms arranged in the middle of a shallow rectangular groove or channel that carries the fuel and by-products from the inlet to the outlet by using a liquid pump. The porous flow field was located within each grid platform and consists of a capillary array, where the capillary number on the platform was limited by the grid size and the capillary action drove the fuel in the reservoir etched on the other side of the electrode plate toward the active reaction site. The directions of the fuel inlet and outlet were opposite each other. The flow field design was determined to obtain an active reaction site, which was $\sim 50 \%$ of the $1 \mathrm{~cm}^{2}$ MEA area. Figure 2 shows the flow field configuration of the combined-mode design. 
(i)

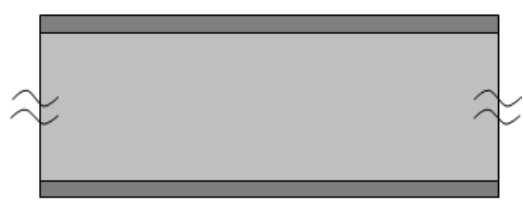

Cleaning of the blank oxidized plate

(iii)

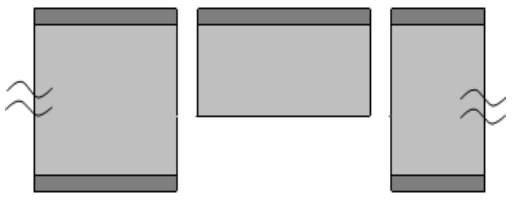

Laser ablation step to etch fuel inlet/outlet
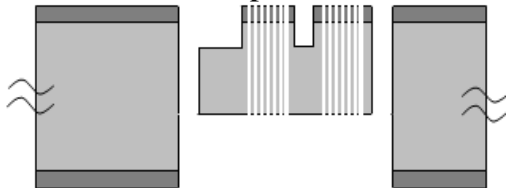

Laser ablation step to etch porous flow field (ii)

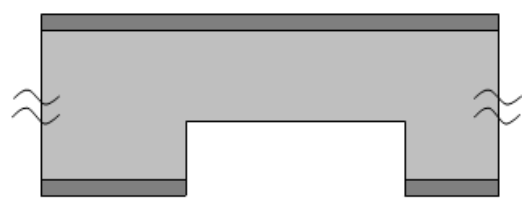

Laser ablation step to etch fuel reservoir
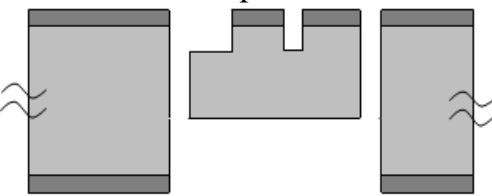

Laser ablation step to etch grid flow field
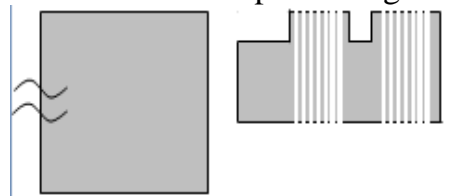

Stripping of the $\mathrm{SiO}_{2}$ layer

Legend:

Silicon $(\mathrm{Si})$

Silicon dioxide $\left(\mathrm{SiO}_{2}\right)$

Figure 1. Process flow using laser ablation for flow field etching of the anode plate.
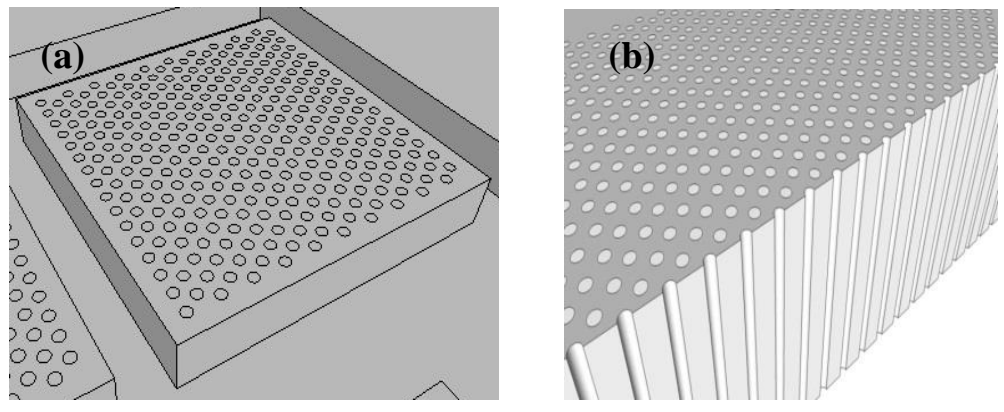

(c)

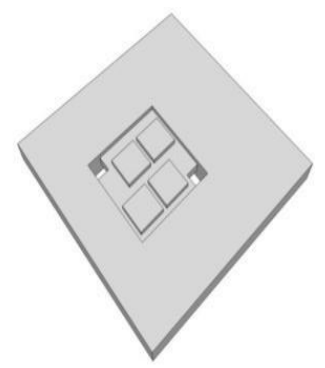

(d)

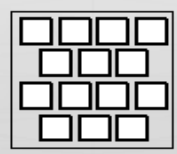

Figure 2. Electrode plate design: (a) the grid-porous anode flow field design, (b) the capillary structure on the grid platform, (c) the fuel inlet and outlet in the opposite position of the anode plate, as well as an overview of the grid design with its channel arrangement, and (d) the square through-hole cathode flow field design 


\section{Dry etching with laser ablation}

The silicon wafer that was used to produce the electrode plate was a $\langle 100\rangle$ p-type single-sided polished substrate with a diameter of 4 inches, a thickness of $500 \pm 20 \mu \mathrm{m}$, and a resistance of $0-20 \Omega \mathrm{cm}$. The MEMS-based microfabrication process that was used to form the required electrode structures was dry etching with laser ablation using the GSI Lumonics W670 Laser Trim System (General Scanning Inc., Somerville, USA). Table 3 provides the details of the laser system settings for dry etching processes in normal operating conditions. This type of laser machine is typically used to trim and test the thickness of the deposition layer and circuit board components such as printed circuit boards and surface-mount technology, but it is also suitable for etching silicon substrate. Its highspeed scanner has an objective lens with an $80 \%$ optical efficiency that focuses the laser beam onto the work surface of the silicon wafer, and the beam can move in the $\mathrm{x}-\mathrm{y}$ direction using the toggle action. The focus distance for the short focus objective was set at $13.5 \mathrm{~cm}$ when the laser was at $100 \%$ power. The laser machine used a software developed and edited in C language and GSI-laser program to carry out the etching process and produce the flow field design required in this work.

Table 3. Laser system for the dry etching process in normal operating conditions

\begin{tabular}{ll}
\hline Operating details & Technical specifications \\
\hline Power requirements & $115 \mathrm{Vac} @ 50-60 \mathrm{~Hz}$ \\
Optical efficiency & $>80 \%$ \\
Field size scan & $10 \mathrm{~cm} \times 10 \mathrm{~cm}$ (with s spot size of $30-50 \mu \mathrm{m}$ at cutting surface) \\
Spot coverage & $\geq 90 \%$ (i.e. minimum diameter/maximum diameter) \\
Beam diameter & $0.12 \mathrm{~cm}$ at $1 / \mathrm{e}^{2}$ power point \\
Beam divergence & $2.0 \mathrm{mrad} \pm 5 \%$ \\
Wavelength transmission & $1.06 \mu \mathrm{m}$ (near-infrared area) \\
Pulse-to-pulse instability & $\pm 5 \% \mathrm{RMS}$ of $500 \mathrm{~Hz}$ to $10 \mathrm{kHz}$ \\
Q-switch pulse width & $100-350 \mathrm{~ns}$ \\
Spectrum sensitivity & $300 \mathrm{~nm}-0 \mu \mathrm{m}$ \\
Rate of pulse repetition & Modified to fit $30 \mathrm{kHz}$ using acousto-optic Q-switch \\
\hline
\end{tabular}

\section{Current collector fabrication}

The etching protective layer was the oxidation layer, $\mathrm{SiO}_{2}$ and the characterization step was carried out after the layer was formed [6]. Silicon wafer is a semiconductor material. Hence, current collectors were needed for electricity conduction, and these were deposited by sputtering conductive metals onto the wafer surface to reduce ohmic resistance in the micro fuel cell. Titanium (Ti), i.e. the adhesive metal film used, was deposited on top of the $\mathrm{SiO}_{2}$ layer followed by the current collector layers from copper $(\mathrm{Cu})$ and gold $(\mathrm{Au})$ materials. Figure 3 shows a schematic of this process, in which the metal target atoms were deposited onto the plate after it was bombarded by argon (Ar) ion in the sputtering chamber.

The Ti layer with a thickness of less than $1 \mu \mathrm{m}$ was deposited to promote the adhesion of the current collector layers onto the plate surface because titanium has good adhesion on a clean surface of silicon, or $\mathrm{SiO}_{2}$, and is often used as an adhesion layer for less sticky metals, such as $\mathrm{Cu}$ and $\mathrm{Au}$. Another metal that is commonly used as an adhesive material for silicon-based plates is chromium [7]. The current collector deposition process consists of two stages: (1) deposition of an electrical conduction layer, i.e., $\mathrm{Cu}$, and (2) deposition of a corrosion resistance layer, i.e. Au. $\mathrm{Cu}$ is much less expensive than $\mathrm{Au}$ and used as the main conductive layer for the current collector because its conductivity is four times higher than that of aluminum and the performance of a micro DMFC increased with the thickness of the $\mathrm{Cu}$ layer [8]. The Au layer is much thinner compared with $\mathrm{Cu}$ and mainly acts as a corrosion resistance layer that covers and protects the $\mathrm{Cu}$ layer from being oxidized in air to a reddish-colored cupric oxide $\left(\mathrm{Cu}_{2} \mathrm{O}\right)$ because it is an undesirable semi-conductive material. Furthermore, the chemical properties of Au are less reactive than those of $\mathrm{Cu}$ in its normal state. Thus, the Au layer can also protect the $\mathrm{Cu}$ layer from direct contact 
with the methanol fuel during operation because $\mathrm{Cu}$ can be eroded by methanol at ambient temperatures, and this corrosion may worsen at high temperatures.

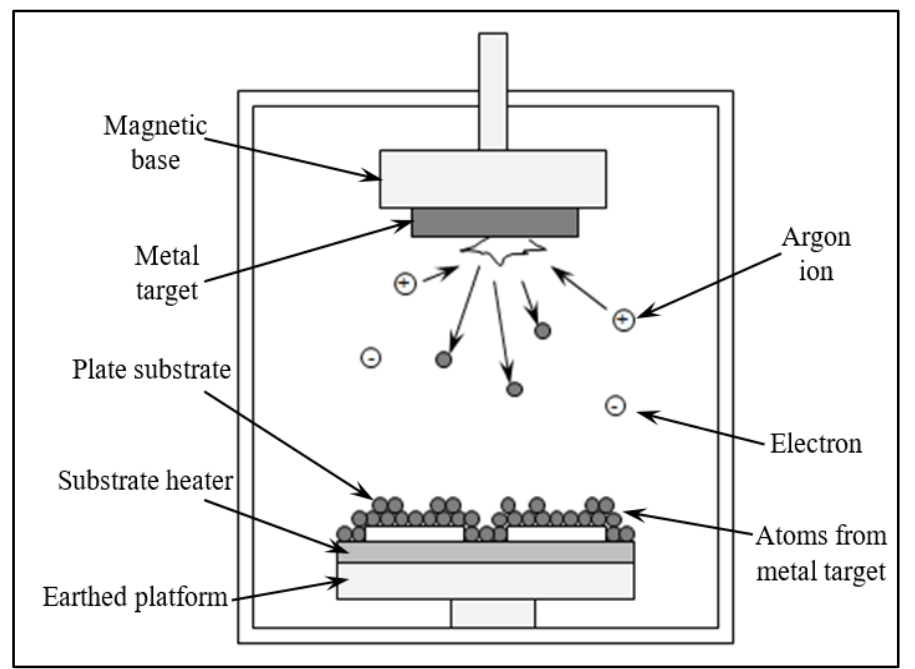

Figure 3. Schematic of the sputtering chamber for $\mathrm{Ti}$ and $\mathrm{Cu}$ targets

\section{Micro fuel cell assembly}

Cell assembly was performed to integrate the electrode plates fabricated in this work and the MEA optimized by means of statistical response surface method (RSM) used in a previous work [9]. The silicon-based electrode plates provided the mechanical support needed and ensured that the mass transport process inside the cell worked as planned. The MEA's active area, which was an area of $1 \mathrm{~cm} \times 1 \mathrm{~cm}$ where the reaction occurred, became the limiting value in determining the total area of the entire electrode plate set at $2.5 \mathrm{~cm} \times 2.5 \mathrm{~cm}$. The remaining area surrounding the active area was required as an electrical contact surface for current collection and a placement area for the sealing gasket during cell assembly. Figure 4 shows the arrangement of the anode and cathode plate areas in conjunction with the MEA from the cell assembly perspective.

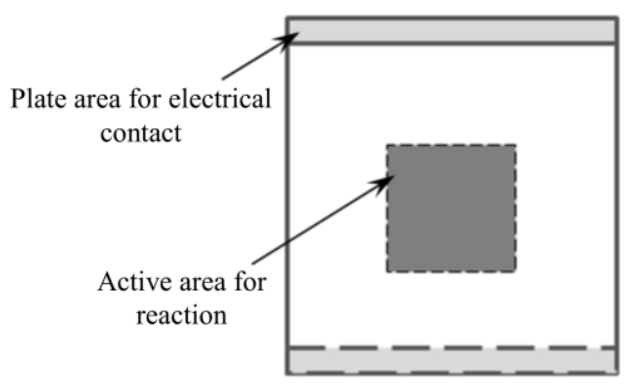

(a)

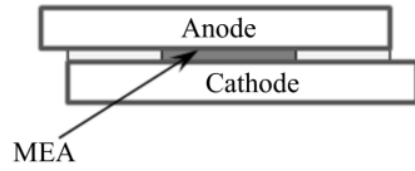

(b)

Figure 4. Illustration of the anode and cathode plate arrangement in conjunction with the MEA: (a) top view and (b) side view

The MEA went through a reprotonation step and was then placed between the electrode plates. A gasket with a thickness of about $50 \mu \mathrm{m}$ was inserted between the plates, and a bonding adhesive was applied to seal the cell to avoid fuel leakage or short circuit between the anode and cathode surfaces. The new micro DMFC was then 
mounted with a PMMA frame, and teflon tubes formed the fuel inlet and outlet. The finished electrode plates were assembled together with the optimized MEA to complete a single-cell micro DMFC and prepare it for performance testing, as shown in Figure 5.
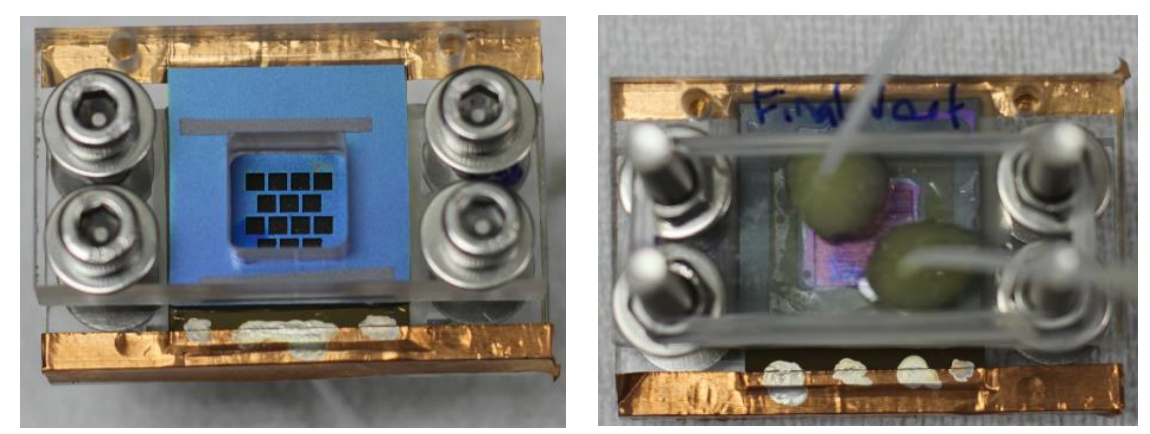

Figure 5. View of the new micro DMFC after assembly for the (a) cathode side and the (b) anode side

\section{Performance test of micro DMFC}

Fuel cell testing was conducted using a WMPG1000 multichannel potentiostat-galvanostat model (WonATech, Korea) to study the performance of the new electrode plate design for different cell orientations. The schematic of the experimental setup is shown in Figure 6. Methanol fuel was pumped into the cell after it passed through the pulse dampener, thereby stabilizing the fuel flow by filling the chamber with air that would be compressed when the liquid pressure increased, given that this condition resulted in a dampening of the flow pulsation. Oxygen was supplied into the cathode side from the surrounding air.

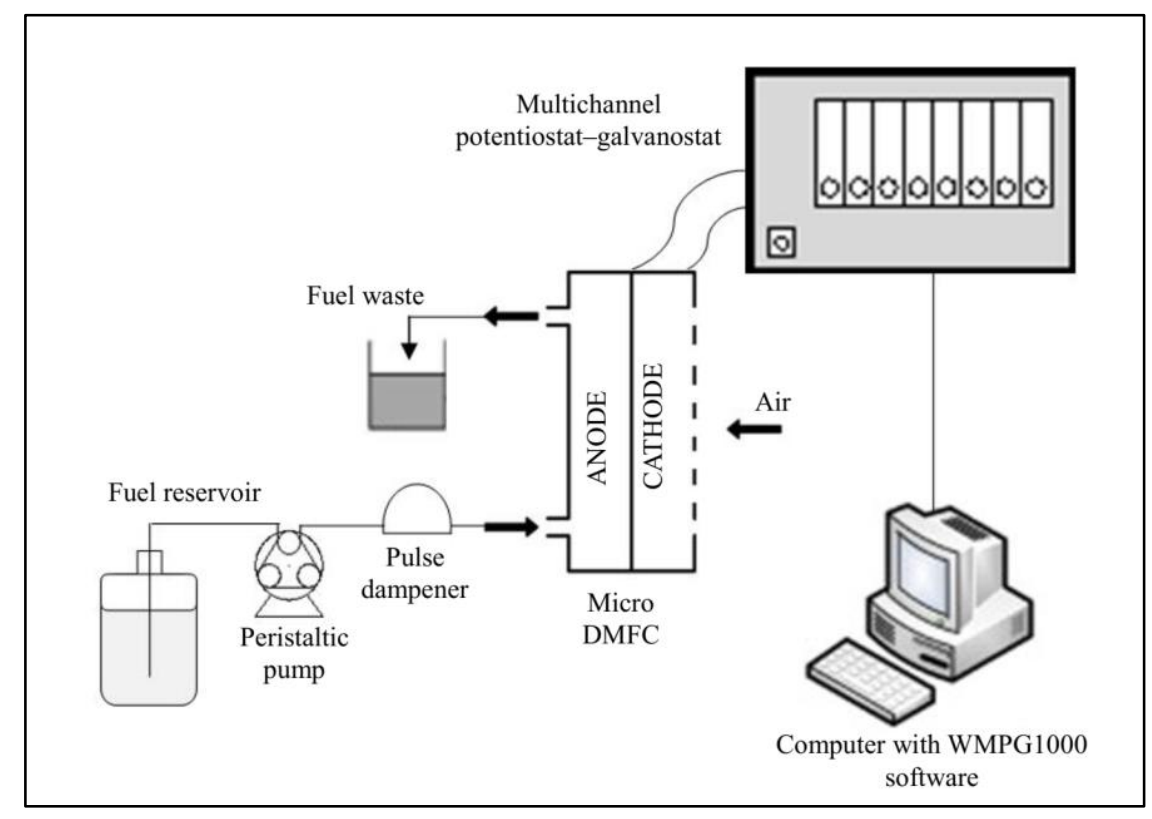

Figure 6. Schematic of cell performance test

\section{Results and Discussion}

The flow field is a new combined grid-porous design where the grid structure, which is the active-mode flow field design, acts as a platform for the capillaries in the porous structure, which is the passive-mode flow field design. 


\section{Umi Azmah et al: Nd:YAG LASER FABRICATION OF SILICON ELECTRODE PLATES FOR A COMBINED-MODE MICRO DIRECT METHANOL FUEL CELL}

Figure 7 shows that a laser beam with a diameter of $\sim 60 \mu \mathrm{m}$ was obtained when the plate surface was exposed to a single laser pulse. Removal of laser ejecta was dominated by explosive vaporization and slag areas comprising micrometer-sized and submicrometer-sized ejecta materials. This situation occurred when the laser beam pulsed with enough energy to reach the melting latent heat of silicon; at this point, its crystals started melting to form a groove. The temperature continued to rise from the melting point to the evaporation point, and the local silicon material was removed when the latent heat of vaporization was reached. Just as the process completed, the evaporation process stopped and the liquid silicon gradually recrystallized when the latent heat was insufficient to maintain its liquidity. A similar phenomenon was observed by Yuan and Ma [10] and O'Neill and Li [11]; this phenomenon resulted in the restrengthening of the Si surface and high shear strength at the groove wall. The influence of q-rate on the laser ablation diameter was less obvious. Figure 7(a) shows a shallow ripple because the laser pulse energy decreased with the increase in frequency and resulted in the decrease in the overall pit size because only the middle part of the laser beam could reach the melting point. By contrast, Figure 7(b) shows that the pit appears to be more pronounced at lower frequencies, but a much larger amount of undesirable recrystallized molten silicon was formed at the edges.

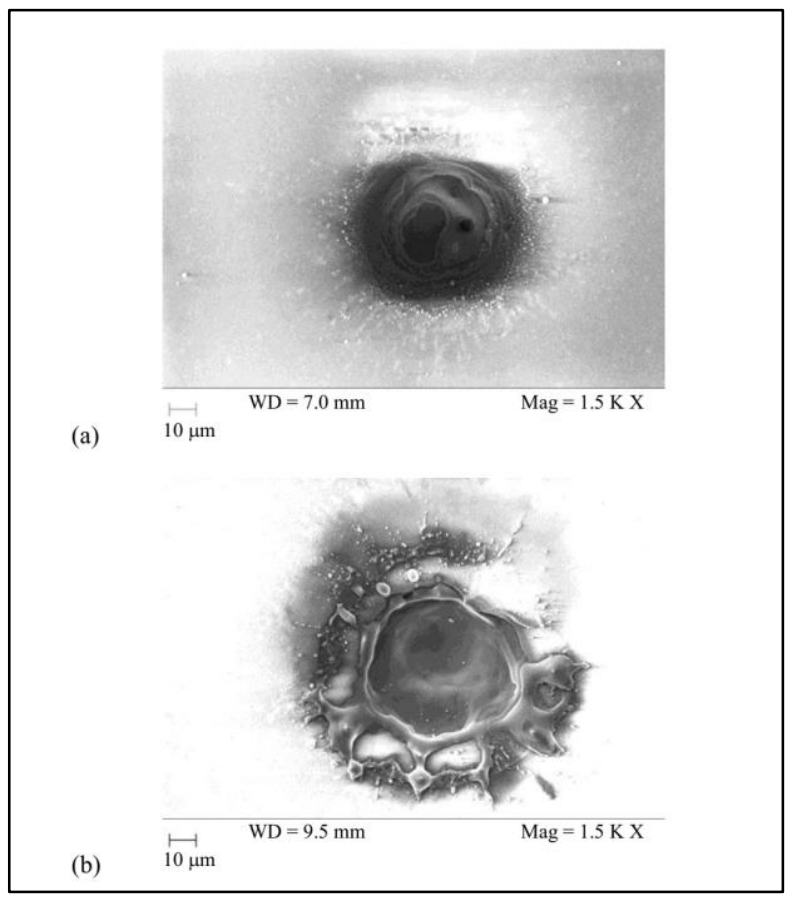

Figure 7. Pit formed by a focused beam point at q-rates: (a) $1 \mathrm{kHz}$ and (b) $3 \mathrm{kHz}$

Figure 8 shows that the laser pulse separation can be influenced by the laser-bit size, i.e., the distance between the pulses increased as the bit size was increased. A comparison shows that if the pulse separation is too small, then the distance between the grooves decreases until the thin walls between adjacent grooves are destroyed and the laser ablation lines overlap with each other, as shown in Figure 8(a). This technique was used to remove a complete $\mathrm{Si}$ layer from the wafer to form the channel and reservoir structures, as well as the fuel inlet and outlet holes required by the flow field design. 


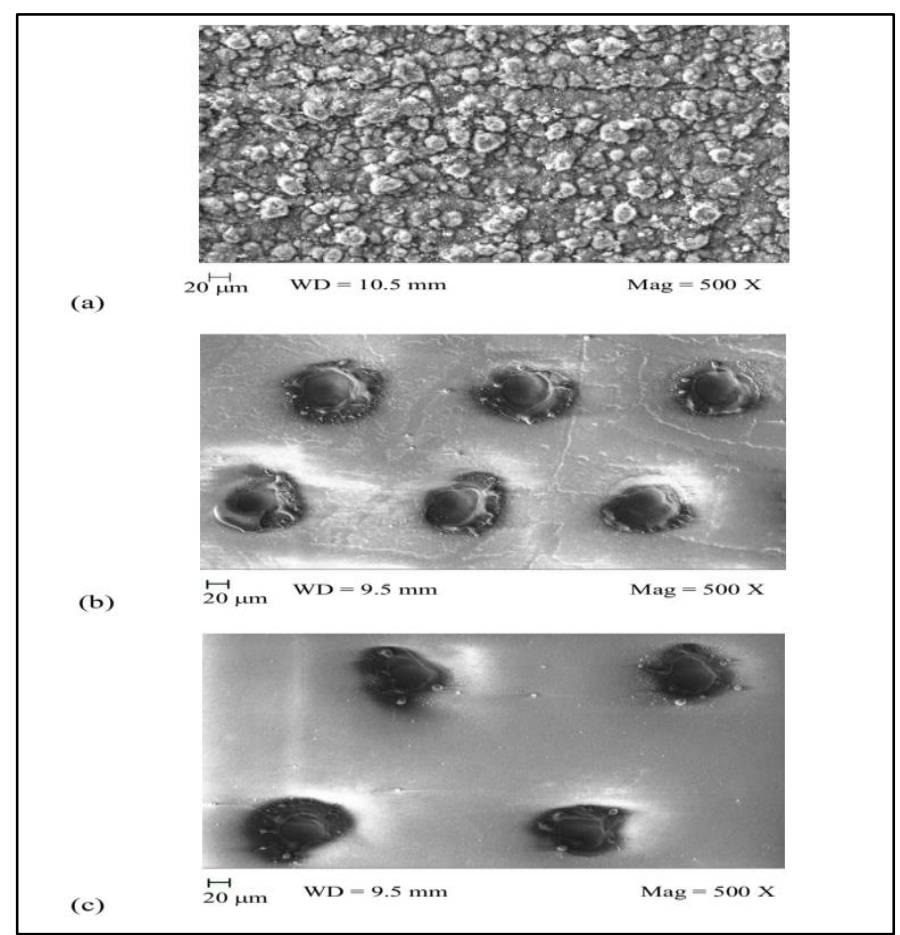

Figure 8. SEM micrographs for the local morphology of capillary structures formed using the bit size (a) 1 mil, (b) 7 mil, and (c) 10 mil.

A $30 \%(\mathrm{w} / \mathrm{w})$ potassium hydroxide $(\mathrm{KOH})$ solution containing $1 \%(\mathrm{v} / \mathrm{v})$ isopropanol (IPA) at $80{ }^{\circ} \mathrm{C}$ was used in the wet etching process to remove the slag surrounding the ablated area. The images of etched holes in Figure 9 were taken by using an Olympus STM6 microscope (Olympus Corporation, Japan) with magnification capabilities of $5 / 10 / 20 / 50 \times$. The desired capillary structure for the porous flow field was determined by monitoring the etching time, which was performed to clean the lasered plate, as shown in Figure 9(a). To maintain the round shape of the capillary structure, the etching process was divided into 5 slots of 1 minute each, and the plate was rinsed with deionized (DI) water at the end of each slot to stop the etching process before proceeding to the next slot, as shown in Figure 9(b). When the plate was continuously etched for more than 2 minutes, the crystal orientation of the $<100>$ p-type $\mathrm{Si}$ wafer used as the electrode plate turned the original round shape of the capillary into a rhombusshaped structure, as shown in Figure 9(c). This slag removal technique resulted in a less-round shape for the capillary structure when the total etching time exceeded 5 minutes.
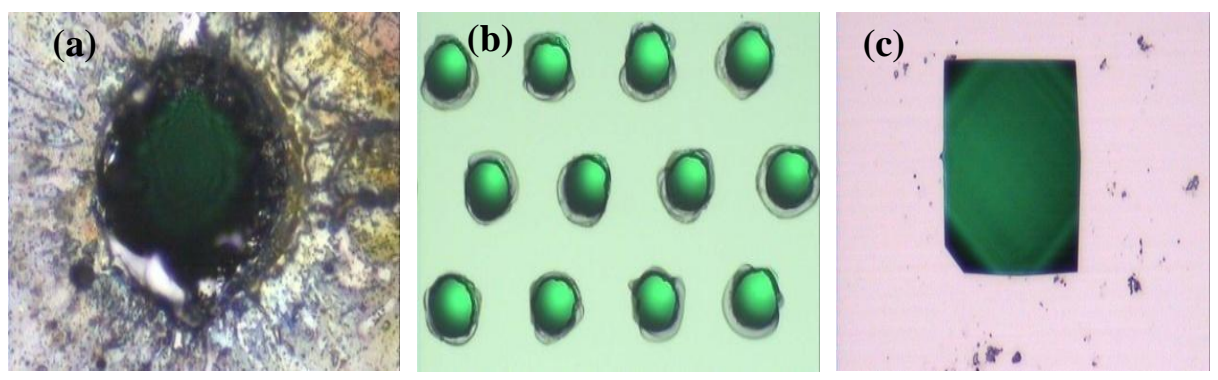

Figure 9. Porous flow field with capillary structure after (a) the laser ablation process, (b) 5 consecutive times of the 1 minute etching slot, and (c) continuous etching for more than 2 minutes 
The channel structure for the grid flow field was formed with laser ablation, as shown in Figure 8(a), and cleaned with the KOH solution, as shown in Figure 10. The number of laser scans required to obtain the desired depth of the fuel reservoir and grid channels was 10 and 5 times, respectively. Figures $10(\mathrm{a}-\mathrm{e})$ show a minute-by-minute wet etching process up to the fifth minute, which was the limiting time set by the cleaning process for the capillary structure. Figure 11 shows a magnification of the three important structures in the grid flow field: the grid platforms, the fuel inlet/outlet holes, and the fuel flow channel. The size of the square grid platforms was limited by the desired $50 \%$ open ratio of the anode active area [12].
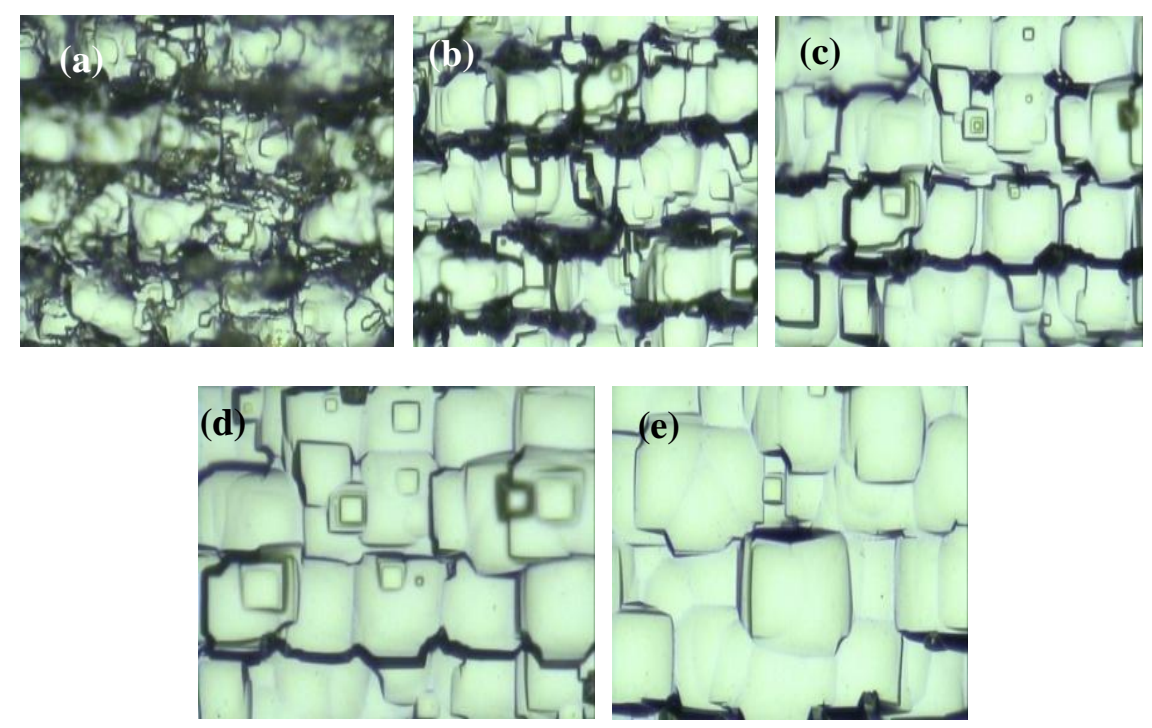

Figure 10. Laser-ablated surface for the channel structure observed using a microscope with $50 \times$ magnification after slag removal with $\mathrm{KOH}$ solution for the (a) $1^{\text {st }}$ minute, (b) $2^{\text {nd }}$ minutes, (c) $3^{\text {rd }}$ minutes, (d) $4^{\text {th }}$ minutes, and (e) $5^{\text {th }}$ minutes

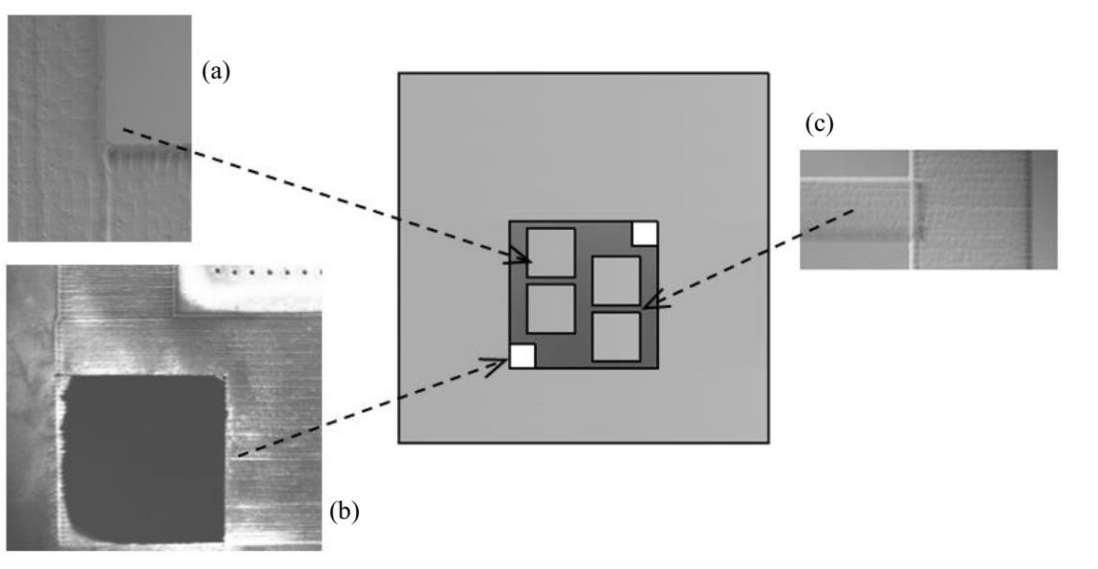

Figure 11. Three important structures in the grid flow field: (a) the grid platforms, (b) the fuel inlet/outlet holes, and (c) the fuel flow channel 
Aside from providing the anode with the MEA contact surface, the grid platforms were also used as the porous flow field site. The inlet/outlet hole diameter was determined by the diameter size of the rigid teflon tube used to conduct the methanol fuel being pumped in and out of the cell, whereas the flow channel dimensions were important to ensure good transport of the reactants and by-products going in and out of the cell, respectively. The height of the grid platforms is also the depth of the fuel flow channel, and this feature became the limiting dimension in the etching process.

After the cleaning process was completed, the plate was rinsed with DI water and the remaining $\mathrm{SiO}_{2}$ protective layer was stripped by soaking the plate in a $10 \%(\mathrm{w} / \mathrm{w})$ hydrofluoric acid solution. Finally, the plate was rinsed with DI water and blow-dried with nitrogen gas. A film thickness measurement mapping instrument, i.e. Filmetrics F50, was used to ensure that the $\mathrm{SiO}_{2}$ layer was completely removed before proceeding to the next step in the process. The scanning electron microscope (SEM) image in Figure 12 shows the height of the grid platform after 5 laser scans, and a value of $113.6 \mu \mathrm{m}$ was obtained, which is satisfactorily comparable to the design value of $100 \mu \mathrm{m}$.

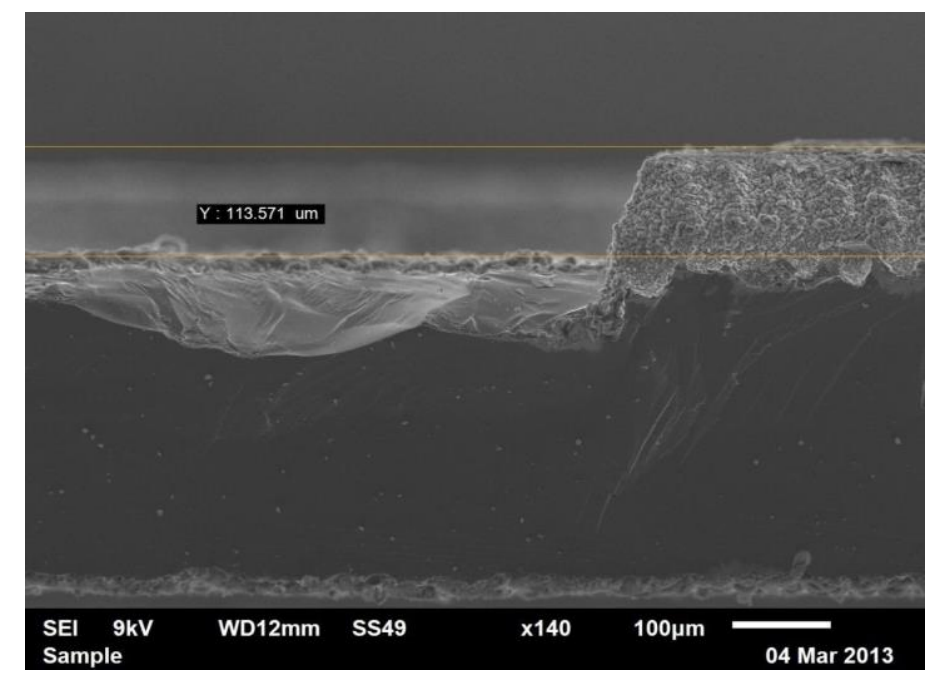

Figure 12. Grid platform structure formed by laser ablation

After the completion of the etching processes, the plate had a blank Si surface. Before the current collectors were deposited onto the plate, the silicon plate underwent a dry oxidation process that lasted for $\sim 5$ hours. The plates were arranged in close proximity to each other in the quartz tube of the mini furnace to promote good oxygen flow in the furnace, thereby resulting in optimum quality and thickness of the desired oxide layer. A thin $\mathrm{SiO}_{2}$ layer with a thickness of about $500 \mathrm{~nm}$ was grown on the silicon surface to give hydrophilic properties to the surfaces of the capillary walls to 'pull' the fuel from the fuel reservoir to the MEA reaction area by increasing the angle of contact between the wall and the fuel and reducing the capillary pressure drop. This non-conductive $\mathrm{SiO}_{2}$ layer also acted as an electrical insulating layer between the current collector layers and the Si substrate.

$\mathrm{Ti}$ and $\mathrm{Cu}$ metal targets of $99.99 \%$ purity were used, and sputtering was performed in an environment with a $1.2 \times 10^{-2}$ Torr operating pressure and a flow rate of $7-14 \mathrm{~s} / \mathrm{cm}$ with the radio frequency sputtering power set at 80 $\mathrm{W}$. The layer thickness depended on the plasma power and the overall gas pressure used for the sputtering process [13]. As these parameters were set before the process, the desired metal thickness was controlled by the sputtering time. The desired thickness of the current collectors was $0.8 \mu \mathrm{m}$ for Ti/Cu layers [14] and the sputtering rates were used as the initial estimates, which were 1.0 and $7.8 \mathrm{~nm} / \mathrm{min}$ for $\mathrm{Ti}$ and $\mathrm{Cu}$, respectively. 
Au metal targets of $99.99 \%$ purity were used, and the sputtering was performed by using a BAL-TEC SCD 005 sputter coater (BalTec Inc, Switzerland) with a 0.3-0.6 Torr operating pressure. At $30 \mathrm{~mA}$ current, an Au layer of $25 \mathrm{~nm}$ was expected to be deposited at a sputtering time of $120 \mathrm{~s}$. Therefore, the sputtering process was performed for 16 minutes to obtain the required thickness of $0.2 \mu \mathrm{m}$. Given the sputter coater conditions, the plate was sputtered twice at $480 \mathrm{~s}$ each before the process was completed [14]. The SEM micrographs in Figure 13 show the cross section of the current collectors after the deposition process. The Ti/Au layers in Figure 13(a) display a column structure, whereas the $\mathrm{Cu}$ layer in the $\mathrm{Ti} / \mathrm{Cu} / \mathrm{Au}$ deposition shows a grain structure. The Au layer thickness in Figure 13(a) was $\sim 0.18 \mu \mathrm{m}$, which gave an average thickness value of Ti/Cu layer of about $1.1 \mu \mathrm{m}$. Both values are close to the targeted $\mathrm{Ti} / \mathrm{Cu} / \mathrm{Au}$ layer thickness.

The performance test that was performed for the cell produced a maximum performance of $1.86 \mathrm{~mW} / \mathrm{cm}^{2}$ at a voltage of $138.7 \mathrm{mV}$. A performance comparison study was conducted between the results of this work and a previous work by Onoe et al. [15], as shown in Table 4. This study was performed is because their work used an anode electrode structure that incorporated a porous design (passive) and serpentine design (active). Unfortunately, their Pt-Ru loading was not stated. Table 4 shows that despite requiring a lower Pt catalyst loading on the cathode side, their micro fuel cell yielded a much lower power output. However, a separate work by Halim et al. [16] proved that the cathode catalyst loading is an insignificant parameter in a micro DMFC. Therefore, a lower Pt loading can be used by the MEA for this new structure in future studies.

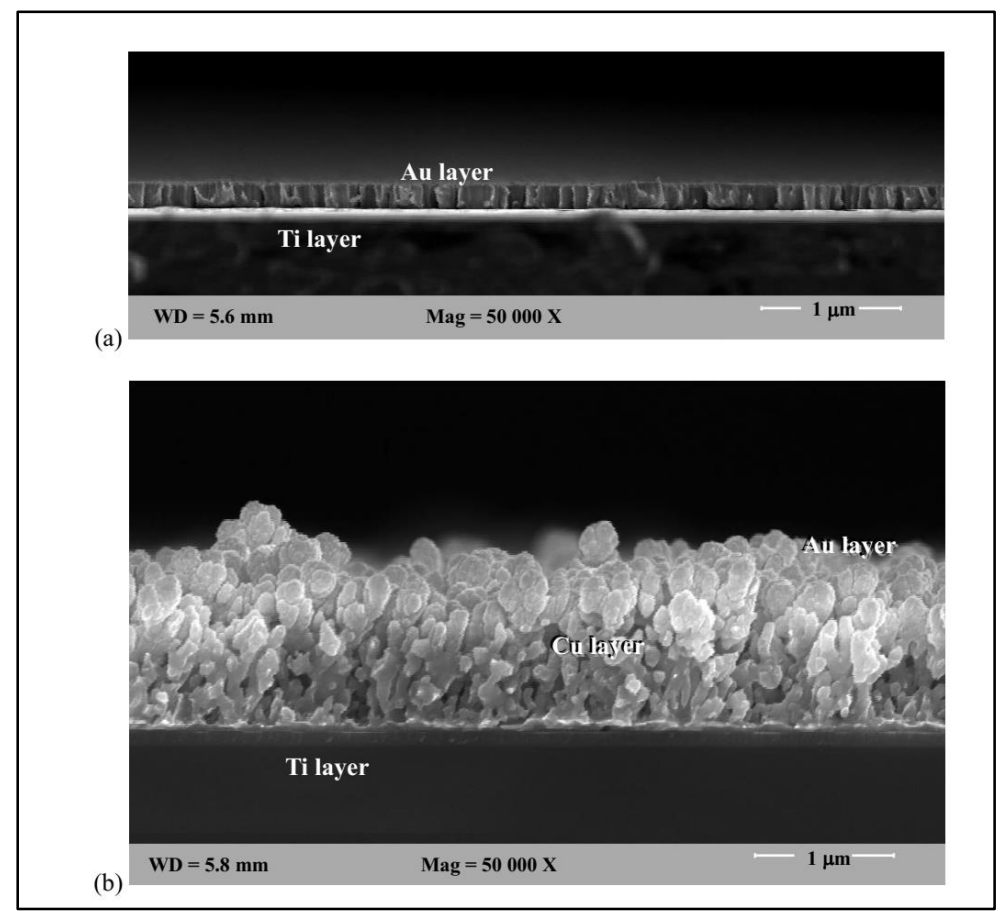

Figure 13. SEM micrographs for the deposited (a) Ti/Au layers and (b) Ti/Cu/Au layers 
Table 4. Performance comparison between the new micro DMFC with a similar combined-mode design

\begin{tabular}{|c|c|c|c|c|c|c|c|}
\hline Ref. & $\begin{array}{c}\text { Active } \\
\text { area } \\
\left(\mathrm{cm}^{2}\right) \\
\end{array}$ & $\begin{array}{c}\text { Methanol } \\
\text { Concentration } \\
(\mathrm{M}) \\
\end{array}$ & $\begin{array}{l}\text { Flow Field } \\
\text { Design }\end{array}$ & $\begin{array}{l}\text { MEA } \\
\text { Materials }\end{array}$ & $\begin{array}{c}\text { System } \\
\text { Type and } \\
\text { Flow Rate } \\
\end{array}$ & $\begin{array}{c}\text { Maximum } \\
\text { Power } \\
\left(\mathbf{m W} / \mathbf{c m}^{2}\right)\end{array}$ & $\begin{array}{l}\text { Fabrication based on } \\
\text { the MEMS Technique }\end{array}$ \\
\hline [15] & 0.64 & 1 & $\begin{array}{l}\text { Serpentine- } \\
\text { porous }\end{array}$ & $\begin{array}{l}\text { Membrane: } \\
\text { Nafion 115; } \\
\text { anode and } \\
\text { cathode: } \mathrm{Pt} \\
\text { (loading: } \\
2.5 \mathrm{mg} / \mathrm{cm}^{2} \text { ) }\end{array}$ & $\begin{array}{l}\text { Active- } \\
\text { passive }\end{array}$ & 0.016 & $\begin{array}{l}\text { The micro channel }(250 \\
\mu \mathrm{m} \text { depth) and the } \\
\text { capillary structure } \\
\text { inside the } 30 \mu \mathrm{m} \\
\text { channel with a } 7 \mu \mathrm{m} \\
\text { diameter is etched by } \\
\text { using the deep reactive- } \\
\text { ion etching process; } \\
\text { current collector: Au } \\
(0.1 \mu \mathrm{m})\end{array}$ \\
\hline $\begin{array}{l}\text { This } \\
\text { work }\end{array}$ & 1 & 5 & $\begin{array}{l}\text { Grid- } \\
\text { porous }\end{array}$ & $\begin{array}{l}\text { Membrane: } \\
\text { Nafion } 117 \\
\text { anode: Pt- } \\
\text { Ru; cathode: } \\
\mathrm{Pt} \text { (loading: } \\
8.0 \mathrm{mg} / \mathrm{cm}^{2} \text { ) }\end{array}$ & $\begin{array}{l}\text { Active- } \\
\text { passive }(2 \\
\text { mL/min) }\end{array}$ & 1.86 & $\begin{array}{l}\text { A micro channel with a } \\
\text { depth of } \sim 100 \mu \mathrm{m} \text { and } \\
\text { inlet/outlet holes were } \\
\text { micromachined using } \\
\text { laser ablation; current } \\
\text { collectors: Ti/Cu }(1.1 \\
\mu \mathrm{m}) / \mathrm{Au}(0.18 \mu \mathrm{m})\end{array}$ \\
\hline
\end{tabular}

\section{Conclusion}

In addition to functioning as an etching mask and protecting the silicon surface from severe damage during the laser ablation process, the $\mathrm{SiO}_{2}$ layer can also provide hydrophilic properties to the capillary wall to reduce the capillary pressure drop and act as an electrical insulating layer between the metallic coating of the current collectors and the Si substrate. Laser ablation was used in a dry etching process to microfabricate an electrode plate that could be used as an anode plate in a micro DMFC. The anode plate flow field was successfully structured to create a new combined-mode design that comprises the grid flow field and porous flow field on a single-plate substrate, which worked well in a micro DMFC. The micro DMFC with the new anode structure produced a maximum performance of $1.86 \mathrm{~mW} / \mathrm{cm}^{2}$ at a voltage of $138.7 \mathrm{mV}$. The silicon-based conductive plate from this work serves as a proof of concept in the field of micro fuel cell research in Malaysia.

\section{Acknowledgment}

The authors gratefully acknowledge the financial support given for this work by the Malaysia Research University Grant (GUP-2016-039) and the Ministry of Higher Education (Malaysia) research grant FRGS/1/2016/TK09/UKM/03/1. The research was conducted with full technical support and assistance at the Fuel Cell Institute Laboratory (Universiti Kebangsaan Malaysia), the IMEN-MEMS Fabrication Laboratory (Universiti Kebangsaan Malaysia), the Microelectronic Fabrication Laboratory (Universiti Malaysia Perlis), and the LIPI Research Center for Electronics and Telecommunication Laboratory (Bandung, Indonesia).

\section{References}

1. Xu, C. and Zhao, T. S. (2007). In situ measurements of water crossover through the membrane for direct methanol fuel cells. Journal of Power Sources, 168(1): 143-153.

2. Chen, X., Li, T., Shen, J. and Hu, Z. (2017). From structures, packaging to application: A system-level review for micro direct methanol fuel cell. Renewable and Sustainable Energy Reviews, 80: 669-678

3. Chen, W., Yuan, W., Ye, G., Han, F. and Tang, Y. (2017). Utilization and positive effects of produced $\mathrm{CO}_{2}$ on the performance of a passive direct methanol fuel cell with a composite anode structure. International Journal of Hydrogen Energy, 42(23): 15613-15622. 
4. Deng, H., Sang, S., Zhang, Y., Li, Z. and Liu, X. (2013). Investigations of silicon-based air-breathing micro direct methanol fuel cells with different anode flow fields. Microelectronic Engineering, 111: 180-184.

5. Yuan, W., Wang, A., Yan, Z., Tan, Z., Tang, Y. and Xia, H. (2016). Visualization of two-phase flow and temperature characteristics of an active liquid-feed direct methanol fuel cell with diverse flow fields. Applied Energy, 179: 85-98.

6. Hasran, U. A., Kamarudin, S. K., Daud, W. R. W., Majlis, B. Y., Mohamad, A. B. and Kadhum, A. A. H. (2011). A simple thermal oxidation technique and $\mathrm{KOH}$ wet etching process for fuel cell flow field fabrication. International Journal of Hydrogen Energy, 36(8): 5136-5142.

7. Williams, K. R., Gupta, K. and Wasilik, M. (2003). Etch rates for micromachining processing - Part II. Journal of Microelectromechanical Systems, 12(6): 761-768.

8. Sung, M.-F., Kuan, Y.-D., Chen, B.-X. and Lee, S.-M. (2011). Design and fabrication of light weight current collectors for direct methanol fuel cells using the micro-electro mechanical system technique. Journal of Power Sources, 196(14): 5897-5902.

9. Hasran, U. A., Kamarudin, S. K., Daud, W. R. W., Majlis, B. Y., Mohamad, A. B., Kadhum, A. A. H. and Ahmad, M. M. (2013). Optimization of hot pressing parameters in membrane electrode assembly fabrication by response surface method. International Journal of Hydrogen Energy, 38(22): 9484-9493.

10. Yuan, W. and Ma, B. (2008). Micro-machinability of monocrystal silicon by direct etching using excimer laser. Journal of Materials Processing Technology, 200(1): 390-397.

11. O'Neill, W. and Li, K. (2009). High-quality micromachining of silicon at $1064 \mathrm{~nm}$ using a high-brightness MOPA-based 20-W Yb fiber laser. IEEE Journal of Selected Topics in Quantum Electronics, 15(2): 462-470.

12. Yang, H. and Zhao, T. S. (2005). Effect of anode flow field design on the performance of liquid feed direct methanol fuel cells. Electrochimica Acta, 50(16-17): 3243-3252.

13. Husna, J., Aliyu, M. M., Islam, M. A., Chelvanathan, P., Hamzah, N. R., Hossain, M. S. and Amin, N. (2012). Influence of annealing temperature on the properties of $\mathrm{ZnO}$ thin films grown by sputtering. Energy Procedia, 25(0): 55-61.

14. Agilent Technologies (2008). A silicon-based air-breathing micro direct methanol fuel cell using MEMS technology. Semiconductor Manufacturing Technology - Elite Development. Retrieved from http://www.paper.edu.cn/download_feature_paper.php?serial_number=AgilentF-02

15. Onoe, S., Tanaka, H., Hoshino, K., Matsumoto, K. and Shimoyama, I. (2005). Miniature fuel cell with conductive silicon electrodes. Paper presented at the $13^{\text {th }}$ International Conference on Solid-State Sensors, Actuators and Microsystems, Seoul, Korea.

16. Halim, F. A. L., Hasran, U. A., Masdar, M. S. and Kamarudin, S. K. (2017). Design of experiment approach for characterization and development of membrane electrode assembly in a passive vapor-feed direct methanol fuel cell. Paper presented at the $6^{\text {th }}$ International Conference on Fuel Cell \& Hydrogen Technology 2017, Putrajaya, Malaysia. 